Johannes Bronkhorst

Section de langues et civilisations orientales

Université de Lausanne

Anthropole 4118

CH-1015 Lausanne

johannes.bronkhorst@unil.ch

\title{
Is there correlative thought in Indian philosophy?
}

(published in: Journal Asiatique 296(1), 2008, 9-22)

A recent article called "Neurobiology, layered texts, and correlative cosmologies"1 by Steve Farmer, John B. Henderson and Michael Witzel (henceforth FHW) argues that correlative thought is not confined to one or just a few cultures. Rather, the deepest roots of correlative thought lie in neurobiological processes. Parallel developments in correlative cosmologies, it is maintained, provide a potent cross-cultural framework for premodern studies in general. This is a very interesting proposition which deserves close consideration. The present article cannot do it full justice, and will merely explore one of its aspects in relation to Indian culture. But before such an exploration can take place, clarification of some of the issues involved must be attempted.

What, to begin with, is correlative thought? FHW use this expression to refer to "a general propensity to organize natural, political/social, and cosmological data in highly ordered arrays or systems of correspondence" (p. 49). Correlative thought is a recognized feature of Chinese culture (since Marcel Granet's La pensée chinoise, 1934) but, FHW maintain, "similar tendencies can be identified in every traditional civilization known". Indeed, "[c]orrelative structures show up world wide in premodern magical, astrological, and divinational systems; in the designs of villages, cities, temples, and court complexes; in abstract orders of gods, demons, and saints; and in many similar phenomena". Our authors then continue: "The idea that reality consists of multiple 'levels', each mirroring all others in some fashion, is a diagnostic feature [10] of premodern cosmologies in general; tracing this idea from its primitive origins to its modern decline is one of the major challenges faced by specialists in premodern thought."

FHW distinguish between correlative thought in general on the one hand, and 'highcorrelative' systems which can arise out of it on the other. High-correlative systems are

\footnotetext{
${ }^{1}$ This article appeared in the volume for 2000 of the Bulletin of the Museum of Far Eastern Antiquities, which came out in 2002.
} 
"multileveled reflecting cosmologies, nested hierarchies, abstract systems of correspondences, and similar developments" and grow "as byproducts of exegetical processes operating in layered textual traditions over extensive periods" (p. 48). Following FHW, we must therefore distinguish two stages, each in need of its own explanation. Here our authors have the following to say (p. 64): "Neurobiology highlights what might be termed the primitive default conditions in correlative thought. But it cannot on its own explain how or why high-correlative systems evolved in advanced premodern civilization." It cannot, because here the layered texts which figure in the title of the article come into play: "Many of the most distinctive features of high-correlative systems can be modeled as syncretic byproducts, or 'exegetical artifacts', of repeated attempts to reconcile conflicts in heavily layered textual traditions."

A further statement about the relationship, and difference, between correlative thought in general and 'high-correlative' systems with special reference to developments in the West can be found in the book Syncretism in the West: Pico's 900 Theses (1486) by S.

A. Farmer (1998), one of the authors of the article under consideration (pp. 83-84):

Renaissance magic ... was grounded on the principles of what since Frazer's time has been commonly referred to as imitative or sympathetic magic. In its nonliterate varieties, imitative magic in all periods in the West differed little from the primitive correlative magic practiced universally in preliterate societies. At its foundations lay loose metaphorical networks potentially linking every object in nature - expressed anthropomorphically, nature's "loves" and "hatreds," "sympathies" and "antipathies." ... In purely oral traditions little effort was made to transform these metaphorical networks into more complex formal systems ... In the literate magical traditions ... the situation was different. Starting in the Hellenistic era, these networks were progressively tightened and systematized, eventually fusing with the broader hierarchical cosmologies of late Greek Neo-Platonism and related traditions.

\section{[11]}

To these two stages - correlative thought and high-correlative systems - a third must be added, corresponding to the "modern decline" mentioned earlier, viz., "the final collapse of those systems in the early scientific era". This collapse, FHW point out (p. 74), is due to some "exceptional nonlinear conditions". In a note (no. 66) they add: "Given their origins in neurobiological processes, correlative tendencies obviously show up in different ways in modern traditions; we plan to discuss this issue elsewhere".

The present article will skip the arguments meant to show the neurobiological foundations of correlative systems. The conclusion seems plausible enough, even though it is less clear, at least to the present author, how the arguments presented lead up to it. We will rather concentrate on the transition from correlative thought in general to high- 
correlative systems in India, a transition which is supposedly due to layered texts and all that accompanies their formation. About this transition FHW provide the following information (p. $51 \mathrm{ff}$.):

Especially rich evidence on the early stages of high-correlative thought survives in early Vedic traditions, preserved in heavily layered texts from the middle third of the first millennium BCE that vastly outnumber extant Chinese and Greek sources from the same period. Correlative ideas in Vedic traditions, often (but not exclusively) referred to as "bandhus" (bandhu= relation, bond, connection, etc.)

have been discussed by a long line of Indologists ... Claims have been made that all of Vedic philosophy depended on what Sinologists would immediately recognize as "correlative thought" - although Indologists do not use that phrase - emerging in increasingly complex and abstract forms in successive strata of tightly linked Brāhmanas, Āranyakas, Upanișads, and Sūtras in Vedic traditions ...

... By the middle of the first millennium BCE, at the latest, we find elaborate high-correlative systems emerging in Vedic traditions as exegetes struggled to harmonize heavily layered ritual texts passed on from earlier eras. To cite just one example: In later strata of the Taittirīya Brāhmana, apparently dating from early in the second half of the millennium, we find elaborate lists of bandhus in which each Vedic god is systematically correlated with unique numbers, consorts, ritual meters, directions, seasons, hours of the day, priestly orders, oblations, sacrificial animals, and similar phenomena. ... Similar correlations are even more fully developed in Vedic Upanișads and Sūtras from the last half of the millennium, which exegetically "worked up" ... earlier traditions in even more abstract directions.

A number of questions present themselves at this point. In this case it is clear what is meant by correlative, even high-correlative, thought, precisely because a long line of Indologists have discussed it (without necessarily using that expression). This however gives rise to the first question: Why should this kind of thought grow "as byproducts of exegetical processes operating in layered textual traditions over extensive periods"? Why should many of its most distinctive features be "syncretic byproducts, or 'exegetical artifacts', of repeated attempts to reconcile conflicts in heavily layered textual traditions"? What exactly happens in exegetical processes that might explain this?

Details about these processes are given in the following passage (FHW p. 69):

One consequence of layering processes was that the texts available ... were increasingly loaded with contradictions; ironically, authorship of those texts was typically ascribed to ancient seers, sage-kings, "school" founders, mythic heroes, prophets, or divine forces, implying exactly the reverse - that those texts could not be contradictory; that every apparent conflict hid secret truths. That assumption led to the application of a broad spectrum of exegetical tools to unveil those truths, resulting in predictable correlative transformations of earlier sources. By the end of the fourth century BCE, developments of this sort were already well on course in the Middle East, Greece, India, and China; repeated use of similar exegetical methods in all these regions resulted in accelerated abstract developments in 
otherwise unrelated religious, philosophical, and cosmological traditions efficiently explaining many so-called axial age effects.

Further ${ }^{2}$ information can be found in another article, "Commentary traditions and the evolution of premodern religious and philosophical systems: a cross-cultural model”, this one by Steve Farmer, John B. Henderson, and Peter Robinson (FHR, 2002). We learn from it that commentators were confronted with the task of reconciling or "syncretizing" traditions (FHR p. 2). They had to free authoritative traditions from internal contradictions or to harmonize them with foreign traditions. One way to attain this goal is the introduction of "scholastic distinctions", for example levels in heaven and hell (FHR p. 3). This process repeated itself numerous times, since the outcome of a preceding [13] "layer" of commentatorial activity is the basis for the next one. Each new layer of tradition, whether embodied in canonical texts or later commentaries, tended to transform the products of earlier strata in predictable ways (FHR p. 5). We can therefore speak of the repetitive application to sacred and semisacred traditions of a relatively small, and largely culturally invariant, series of commentatorial techniques. The commentators were obliged, not only to syncretize opposing or foreign traditions, but also to harmonize conflicting layers of canonical texts (FHR p. 6).

The results of this multi-layered commentatorial activity could generate, among other things, abstract pantheons of gods, monotheistic deities, or abstract ethical or cosmological principles. In later traditions, our authors maintain, typical products included dualistic or trinitarian concepts of deity, broad systems of correspondences, multileveled pictures of heaven or hell, elaborate emanational systems, and other diagnostic features of scholastic traditions. They add: "Over many centuries, higher-level integrations of structures like these gave birth to elaborate multilayered correlative systems - NeoPlatonic, Neo-Confucian, Buddhist, Hindu, Islamic, or Christian cosmologies, etc. whose levels of self-similarity tended to increase whenever those traditions inbred and grew in complexity." (FHR p. 6).

It is more or less understandable that the obligation to make sense of "syncretizing" traditions may have led commentators to pursue a number of exegetical strategies, such as identifying gods from different traditions, making place for "foreign" gods by introducing refined distinctions, etc. etc. It is harder to understand why this should inevitably lead to correlative or even high-correlative thought. What exegetical situation would be solved by systematically correlating "each Vedic god ... with unique numbers, consorts, ritual meters,

\footnotetext{
${ }^{2}$ Most of the following two paragraphs occurs verbatim in Bronkhorst, 2006.
} 
directions, seasons, hours of the day, priestly orders, oblations, sacrificial animals, and similar phenomena"? No answer is even attempted by our authors, as far as I can see.

This takes us to a second question: What reason is there to believe that the highcorrelative systems which we find in Vedic literature are the result of multi-layered commentatorial activity trying to free the own tradition from internal contradictions or to harmonize them with foreign traditions? To the best of my knowledge there is none whatsoever. The [14] high-correlative thought present in Vedic literature is no doubt extremely interesting, and its parallels with similar phenomena in China and the West have not sufficiently been studied. But far from being the result of multi-layered commentatorial activity of the kind described, it creates the impression of being a more or less consciously cultivated characteristic of Vedic society, especially in late-Vedic times, which sought to distinguish itself in this way from others. ${ }^{3}$

The passage about India cited above continues as follows (FHW p. 53-54):

Correlative systems of still greater complexity, especially rich in numerological associations, are found in early Buddhist and Jainist texts compiled near the close of the millennium.

By the early common era, centuries of reworkings of these layered texts had given birth to high-scholastic systems of extraordinary elaboration. These developments are beautifully illustrated in the intricate logical-mystical constructs of the massive seventh book of the Buddhist Abhidhamma Pitaka ... Correlative systems of the same general type as those seen in post-classical Daoism in China, or in contemporary gnostic, Neo-Pythagorean, or Neo-Platonic traditions in the West, can be studied in later strata of the Mahābhārata and Purānas, in countless tantric and mandala sources, and in late-ancient and medieval scholastic systems subdivided (just as elsewhere in the Old World) into a profusion of warring "schools". Fresh developments in these systems continued to appear up through the Mughal period, exhibiting structural features similar to those seen in contemporary high-syncretic systems from the European Renaissance or Ming dynasty. These parallel developments can be simply explained by the fact that those systems arose from integrations of layered traditions whose temporal depth and complexities were of roughly the same magnitude in each previous stage of history, stretching from the mid first millennium BCE until early modern times.

This passage is not as clear as one might wish. It concerns post-Vedic India, but does not refer to any secondary literature, unlike the part dealing with the Vedic period. For this later period it mentions as sole example of presumably high-correlative thought a book from the Abhidhamma Pitaka of Theravāda Buddhism. The reason for this is no doubt to be sought in the remark, made on p. 54, saying that "while bandhus [15] and upaniṣads in Indian

\footnotetext{
${ }^{3}$ Bronkhorst, 1999: 52-53; 2007 (esp. ch. IV.1 "Discworld meets roundworld"). Note that the idea that Vedic culture is syncretistic is not new; see, e.g., Parpola, 1997.
} 
traditions have been discussed continuously since the nineteenth century, the importance assigned to correlative thought by Indologists has never approached the levels found in Chinese studies, hampering the comparison of cosmological developments in the two civilizations". This suggests that there simply is no secondary literature about correlative thought (by whatever name it may be called) in post-Vedic Indian literature. The cited passage shows, however, that in FHW's opinion the presence of high-correlative thought in those later Indian sources is obvious and undeniable. More in particular, their remark to the extent that "[c]orrelative systems ... can be studied ... in late-ancient and medieval scholastic systems subdivided ... into a profusion of warring "schools"' suggests that what is commonly referred to as "Indian philosophy" exemplifies correlative thought. This is remarkable. The presence of "high-correlative" thought in the Veda is clear and beyond doubt. This literature also constitutes its pinnacle. Similar ways of thinking, especially about cosmic correspondences, find expression later on in certain genres of literature, prominently among these Tantric literature, ${ }^{4}$ but never again with the same intensity.

In this context it is of interest to consider an article by Michael Witzel called "Macrocosm, mesocosm, and microcosm: The persistent nature of 'Hindu' beliefs and symbolic forms" (1997). This article suggests continuities and analogs of some structures of modern Newar Hinduism with those of the Vedic period. Some of these persistences include the procedure found in the Brāhmana texts of analyzing the universe on three levels and connecting these by a series of 'identifications' (homologies), for example, and the use of 'creative etymologies' (p. 503). All this seems to confirm that "(high-)correlative thought", where present in post-Vedic India, continues a Vedic tradition. There is no suggestion that exegetical strategies have to be invoked to explain its presence in recent forms of Hinduism.

We will return to these issues in a while. Let us first try to get a fuller grasp of FHW's ideas. One of the studies on which their article is based is the book Scripture, Canon, and Commentary: A comparison of Confucian and Western exegesis by John B. Henderson (1991), one of the [16] authors of the article that engages our attention. The title of this book suggests that it may contain information as to how high-correlative systems come about. Remember FHW's statement, already quoted above: "Many of the most distinctive features of high-correlative systems can be modeled as syncretic byproducts, or 'exegetical artifacts', of repeated attempts to reconcile conflicts in heavily layered textual traditions." Scripture, Canon, and Commentary does indeed discuss a general commentatorial assumption, viz., that the canon is self-consistent, that internal

\footnotetext{
${ }^{4}$ Cf. Filliozat, 1999.
} 
contradictions in it are only apparent (p. 115 ff.). But it says nothing about high-correlative systems that arise as byproducts. It says nothing about correlative thought, and indeed, neither this expression nor other ones such as "correspondences" can be found in the index. More relevant material can be found in Farmer's Syncretism in the West. The following passage deals with the issue that concerns us (p. 74):

Syncretic methods like Pico's had systematic effects that were remarkably similar no matter what traditions were being fused. The historical significance of these methods lies here, since they illuminate otherwise mysterious parallels in the evolution of traditions. These effects were clearer in literate than in oral traditions, whose fluidity permitted syntheses in flexible and impermanent ways.

Reconciliations of literate traditions, however, required the use of formal syncretic methods like those planned by Pico for his Vatican debate. The systematic effects of these methods were cumulative and are best observed evolving in traditions over vast periods of time. ...

The most obvious result of the use of these methods was the sheer complexity that they introduced into systematic thought. When religious and philosophical exegetes could not harmonize the conflicting concepts of their authorities more directly, the tendency was to carve out niches for all those concepts somewhere in their systems. The results of this compilational mode of thought were much the same whether room for those concepts was created by use of a standard scholastic distinction, by some variation of the double-truth, or by the invention of cosmic correlations and hierarchical distinctions to preserve their full or partial truth.

The last sentence of this passage is particularly interesting. It emphasizes that room for conflicting concepts could be created "by use of a standard scholastic distinction, by some variation of the double-truth, or by the invention of cosmic correlations and hierarchical distinctions". It does [17] not state that each of these ways had to be used in each tradition. One could easily imagine a culture which, for reasons of its own, avoids one or more of these methods, for example the invention of cosmic correlations. That is to say, one may sympathize with the model presented by Farmer c.s. without feeling obliged to look for high-correlative thought presumably resulting from the processes included in it. India may well be an example that shows that high-correlative thought cannot be counted among its necessary consequences, and indeed that high-correlative thought can come about in other ways. This culture has its share of high-correlative thought, primarily (though not exclusively) in Vedic literature, but it is not the result of the iterated application of exegetical methods. It is not my intention to offer an alternative explanation for the presence of correlative thought in certain literary manifestations of Indian culture, but FHW's claim to the effect that it has a neurobiological basis, combined with the further 
claim that certain religious currents may believe that this kind of thought provides access to hidden levels of reality, ${ }^{5}$ might go at least part of the way.

Let us now turn to the "late-ancient and medieval scholastic systems subdivided (just as elsewhere in the Old World) into a profusion of warring 'schools", (FHW p. 54), which includes no doubt the different schools of Indian philosophy. Resolving contradictions was no doubt a prime concern of these philosophical schools. This led them to systematize their thought, but not to produce high-correlative systems. Correlative thought is weak or even totally absent in most of them. One reason may be that these systems are not the result of iterated exegetical processes based on ever more-inclusive canonical texts. During the classical period each philosophical school rather has one basic text, and the differences between the schools are not differences of interpretation, but differences that are at least in part already enshrined in the fundamental texts of each of them.

Correspondences as we find them in Vedic literature are absent from classical Brahmanical philosophy. We do occasionally find traces of the [18] identification of macrocosm and microcosm. An example is the Sāmkhya philosophy which, still in its classical formulation, appears to confuse the two levels. Eli Franco (1991: 123 f.) puts it like this: "One of the reasons why many of us feel uneasy with the Sāmkhya philosophy is that we are never quite sure where we stand and whether the ancient teachers were talking psychology or cosmology. Typical psychological and individual terms like cognition, ego, mind, sense organs, and even hands, feet, tongue, anus and penis, become trans-individual and obtain cosmological dimensions." In the present context it is important to observe that this identification of macrocosm and microcosm is not only a problem for the modern researcher. The tradition itself, including its classical commentaries, was concerned with it, and made efforts to remove it. ${ }^{6}$ The philosophy of Bhartrhari contains a similar ambiguity, but the more recent Utpaladeva who appropriated part of his thought made sure that it was removed. ${ }^{7}$

Mīmāmsāa is the school of Vedic hermeneutics which is the only "school of philosophy" that is interested in the Vedic texts that display high-correlative thought. Though interested in these Vedic texts, Mīmāmsā is not interested in high-correlative thought. Sentences or passages expressive of high-correlative thought are barely ever cited

\footnotetext{
${ }^{5}$ I assume that also FHW will agree that not all hidden levels of reality are to be explained through iterated exegetical processes.

${ }^{6}$ See on all this Bronkhorst, 1999a; 2001: $§ 5 \& 8$.

${ }^{7}$ Bronkhorst, 2001: $\$ 6$.
} 
in its works, ${ }^{8}$ and the school itself does not utilize it. The other school of Mīmāmsā which is better known by the name Vedānta (or Brahma-Mīmāṃsa, later also Uttara-Mīmāmsāā) concentrates its attention on some Upanișadic sentences. ${ }^{9}$ Some of these - such as tat tvam asi "that you are" - might conceivably be interpreted in terms of correlative thought, ${ }^{10}$ but the Vedāntic interpreters do not do so.

Particularly interesting in connection with the theory of Farmer c.s. is the philosophy of the Jainas. Unlike their Brahmanical and Buddhist counterparts, who criticized each other's views virtually without restraint, the Jaina thinkers made a concerted effort to reconcile the views of their opponents with their own from an early time onward. The result was a [19] philosophical relativism typical of Jainism. The efforts of the Jaina philosophers - reconciling conflicting remarks in the early scriptural tradition, ${ }^{11}$ attempting to find a place for the 'partial truths' of other philosophical schools - seem to coincide to a remarkable degree with the activities which exegetes are supposed to carry out in the model of Farmer c.s. Here then, if anywhere in the context of classical Indian philosophy, one might expect to see the "byproduct" of the model which is the creation of high-correlative systems.

One doesn't. There is no correlative thought in Jaina philosophy. There are, on the other hand, lots of "modes of consideration" (naya). The other schools of Indian philosophy do not even have those. Their thinkers present one vision of reality, which they do not feel obliged to syncretize with the views of others. It would seem that the classical Indian tradition of philosophical thought quite simply does not fit in the model presented by Farmer and his co-authors. $^{12}$

What do we conclude from these observations? The suggestion that correlative thought, or even high-correlative systems of thought, develop "as byproducts of exegetical processes operating in layered textual traditions over extensive periods" has a certain a priori plausibility and exerts a certain a priori attraction. However, intellectual history is not, or not exclusively, deduced from theoretical a prioris. This theory may be of help in

\footnotetext{
${ }^{8}$ Cf. Garge, 1952.

${ }^{9}$ See Bronkhorst, 2007a.

${ }^{10}$ This would not be the original interpretation of this sentence; see Brereton, 1986.

${ }^{11}$ See Dundas, 1992: 197 f; $2^{\text {nd }}$ ed. p. 229 f., and esp. p. 198 (230): “The catalyst for the emergence of philosophical relativism was the condensing by Umāsvāti in the Tattvārthasūtra of the often inchoate and unconnected remarks found in the early scriptural tradition concerning substance and its modifications and the standpoint from which they should be approached into the definitive expression of a distinctively Jain model of reality as simultaneously involving the two apparent contradictories of permanence and change." See further Bronkhorst, 2003.

${ }^{12}$ For a recent overview of the main doctrinal positions of the early Indian philosophical schools, see Bronkhorst, 2008.
} 
understanding certain developments in cultures different from India. In India it does not appear to have much to offer. The high-correlative systems of thought which we do find in India have not, as far as we can tell, developed in the manner postulated by the theory. And the systems of thought (primarily the systems of Indian philosophy) which should, by dint of this theory, be high-correlative systems of [20] thought, are not. It seems justified to discard the theory as of little use in the Indian context, and to conclude that it does not possess the universal characteristics claimed by its authors.

\section{References:}

Brereton, Joel (1986): “"Tat tvam asi’ in context.” Zeitschrift der Deutschen Morgenländischen Gesellschaft 136, 98-109.

Bronkhorst, Johannes (1999): "Is there an inner conflict of tradition?" Aryan and NonAryan in South Asia: Evidence, Interpretation and Ideology. Proceedings of the Michigan-Lausanne International Seminar on Aryan and Non-Aryan in South Asia, University of Michigan, Ann Arbor, 25-27 October 1996. Ed. Johannes Bronkhorst \& Madhav M. Deshpande. Cambridge, Mass.: Department of Sanskrit and Indian Studies, Harvard University. 1999. (Harvard Oriental Series, Opera Minora Vol. 3.) Distributed by South Asia Books, Columbia, Missouri. Pp. 33-57.

Bronkhorst, Johannes (1999a): "The contradiction of Sāmkhya: on the number and the size of the different tattvas." Asiatische Studien / Études Asiatiques 53(3) (Proceedings of the Conference on Sāmkhya, Lausanne 6-8 November 1998), pp. 679-691.

Bronkhorst, Johannes (2001): "Indology and rationality." Asiatische Studien / Études Asiatiques 55(4), 917-941. (Reprint in: Indology: Past, Present and Future, ed. Saroja Bhate, New Delhi: Sahitya Akademi, 2002, pp. 142-173.)

Bronkhorst, Johannes (2003): "Jainism's first heretic and the origin of anekānta-vāda." Jainism and Early Buddhism: Essays in Honor of Padmanabh S. Jaini. Ed. Olle Qvarnström. Fremont, California: Asian Humanities Press. Pp. 95-111.

Bronkhorst, Johannes (2006): "Commentaries and the history of science in India." Asiatische Studien / Etudes Asiatiques 60(4), 773-788.

Bronkhorst, Johannes (2007): Greater Magadha. Studies in the culture of early India. Leiden - Boston: Brill. (Handbook of Oriental Studies, Section 2 South Asia, 19.)

Bronkhorst, Johannes (2007a): "Vedānta as Mīmāmsāa." Mīmāmsāa and Vedānta: Interaction and Continuity. Ed. Johannes Bronkhorst. Delhi: Motilal Banarsidass. (Papers of the 12th World Sanskrit Conference, 10.3.) Pp. 1-91.

Bronkhorst, Johannes (2008): Aux origines de la philosophie indienne. Gollion: Infolio éditions.

Dundas, Paul (1992): The Jains. London and New York: Routledge. Second edition, 2002.

[21]

Farmer, S. A. (1998): Syncretism in the West: Pico's 900 Theses (1486). The Evolution of Traditional Religious and Philosophical Systems. With text, translation, and commentary. Tempe, Arizona. (Medieval \& Renaissance Texts \& Studies, 167.)

Farmer, Steve; John B. Henderson; Michael Witzel (2000): "Neurobiology, layered texts, and correlative cosmologies: a cross-cultural framework for premodern history." Bulletin of the Museum of Far Eastern Antiquities 72, 2000 [2002], 48-90. Also: http://www.safarmer.com/neuro-correlative.pdf. 
Farmer, Steve; John B. Henderson; Peter Robinson (2002): "Commentary traditions and the evolution of premodern religious, philosophical, and cosmological traditions: a cross-cultural model." http://www.safarmer.com/model.pdf.

Filliozat, Pierre-Sylvain (1999): "Homologies du monde, de la parole et de l'homme dans les religions de l'Inde (des Veda aux Tantra)." Ressembler au monde: Nouveaux documents sur la théorie du macro-microcosme dans l'antiquité orientale. Réunis par Philippe Gignoux. Turnhout: Brepols. Pp. 11-40.

Garge, Damodar Vishnu (1952): Citations in Sabara-Bhāṣya. Poona: Deccan College. (Deccan College Dissertation Series, 8.)

Henderson, John B. (1991): Scripture, Canon, and Commentary. A comparison of Confucian and Western exegesis. Princeton, New Jersey: Princeton University Press.

Parpola, Asko (1997): "The Dāsas and the coming of the Aryans." Inside the Texts, Beyond the Texts. New approaches to the study of the Vedas. Ed. Michael Witzel. Department of Sanskrit and Indian Studies, Harvard University. Distributed by South Asia Books, Columbia, MO. (Harvard Oriental Series, Opera Minora, 2.) Pp. 193-202.

Witzel, Michael (1997): "Macrocosm, mesocosm, and microcosm: the persistent nature of 'Hindu' beliefs and symbolic forms." International Journal of Hindu Studies 1(3), 501-539.

Abbreviations:

FHR Steve Farmer, John B. Henderson and Peter Robinson

FHW Steve Farmer, John B. Henderson and Michael Witzel 